Kiryoku, Volume 3 No 22019

e-ISSN: 2581-0960 p-ISSN: 2599-0497

Tersedia online di http://ejournal.undip.ac.id/index.php/kiryoku

\title{
KONSEP MURA DALAM ANIME KASAJIZOU
}

\author{
Zaki Ainul Fadli \\ Program Studi Bahasa dan Kebudayaan Jepang, Fakultas Ilmu Budaya, Universitas \\ Diponegoro \\ Email: zakiaf@live.undip.ac.id
}

\begin{abstract}
Abstrak
Artikel ini bertujuan untuk mengungkap konsep mura dalam anime dongeng Kasajizou . Mura merupakan salah satu sistem tradisional Jepang selain ie dan kuni. Metode penelitian yang digunakan adalah pendekatan sosiologi sastra, yaitu dengan mengungkap salah satu struktur anime yaitu latar "mura " dalam anime tersebut dan mengaitkannya dengan "mura "sebagai suatu konsep teritori dalam tradisi Jepang. Hasil penelitian menunjukkan bahwa "mura " dalam anime dongeng Kasajizou mirip dengan konsep mura yang dipaparkan oleh Inagaki, yaitu sebuah organisasi lokal untuk tujuan produksi dan sebagai komunitas yang terbentuk secara alami untuk dewa yang melindungi daerah itu. Kesimpulannya, konsep mura dalam anime dongeng tersebut menegaskan paparan Inagaki mengenai mura sebagai salah satu elemen dalam sistem tradisional masyarakat Jepang.
\end{abstract}

Kata kunci: Kasajizou ; anime; dongeng; mura ; sistem tradisional masyarakat Jepang

\begin{abstract}
(Title: "Mura" Concept in Kasajizou Anime) This article aims to uncover the concept of mura in the Kasajizou anime. Mura is one of the traditional Japanese systems, besides ie and kuni. The research method used is the literary sociology approach, namely by revealing one of the anime's structures (mura 'background) in the anime and relating it to "mura " as a territorial concept in Japanese tradition according to Inagaki's explanation. The results showed that "mura" in the fairy tale anime Kasajizou was similar to the concept of mura which was presented by Inagaki, which is a local organization for the purpose of production and as a community formed naturally for the god who protected the area. In conclusion, the concept of mura in the fairytale anime confirms Inagaki's exposure of mura as one of the elements in the traditional system of Japanese society.
\end{abstract}

Keywords: Kasajizou; anime; fairy tale; mura; traditional system of Japanese society

\section{PENDAHULUAN}

Jepang adalah negara yang banyak menarik perhatian karena dianggap memiliki karakter yang khas dalam masyarakatnya. Tentu saja ini menjadi perdebatan karena Jepang selalu dilihat dari kacamata bangsa Eropa yang kemudian menuliskan banyak teori mengenai masyarakat Jepang. Sebagai contoh, karakter nasional Jepang telah menarik banyak orang yang mempelajari masyarakat Jepang dan rakyatnya. Apa yang disebut di sini sebagai karakter nasional Jepang adalah gabungan dari karakteristik perilaku yang secara konvensional disebut groupism atau budaya "berkelompok".

Pola ini seringkali berlawanan dengan individualisme Barat, sehingga sering kali dikarikaturkan, dibesarbesarkan, dan distereotipkan. Karakter Ini 
bertepatan dengan meningkatnya kepercayaan di antara orang Jepang sendiri dalam apa yang dianggap sebagai sifat "Jepang". Selain orientasi "berkelompok" yang sering dibandingkan dengan individualisme ala Barat, ada pula yang mencoba melabeli budaya Jepang sebagai "budaya rasa malu", yang berbeda dengan "budaya rasa bersalah" bangsa Barat (Ryoko, 2019, p. 70).

Tulisan lain berkaitan dengan masyarakat Jepang adalah berkaitan dengan stratifikasi masyarakat tradisional Jepang, khususnya pada zaman Edo, yaitu stratifikasi yang disebut dengan shi-no-koso, yaitu bushi atau kelas samurai, noumin atau kelas petani, shokkou atau kelas pekerja, dan shounin atau kelas pedagang (Suherman, 2004). Artikel Suherman tersebut bertujuan untuk mengungkap dinamika masyarakat Jepang mulai zaman Tokugawa sampai zaman Shouwa. Hasilnya, pada perkembangan selanjutnya stratifikasi shi-no-ko-soo yang dikenal pada zaman Edo tersebut mengalami perubahan dan berganti menjadi tiga strata sosial, yaitu kazoku, shizoku, dan heimin. Meskipun pembagian kelas ini kemudian dihilangkan pada zaman Meiji, tetapi pada praktiknya masih tampak dalam kehidupan sehari-hari sampai zaman Shouwa.

Artikel ini bertujuan untuk mengungkap salah satu konsep sistem tradisional Jepang berdasarkan pandangan Inagaki, yaitu "mura " yang terdapat di salah satu karya sastra Jepang yaitu Anime Kasajizou. Versi anime Kasajizou yang digunakan adalah versi anime yang dipublikasikan oleh akun kizzubonbon (Kasajizou, n.d.). Anime Kasajizou diadopsi dari dongeng Kasajizou yang ceritanya berkembang di Jepang.

Kasajizou adalah salah satu dongeng Jepang, dan salah satu dongeng rakyat paling populer. Dongeng ini berkisah keberuntungan yang tak terduga yang diterima orang yang baik hati sebagai hadiah atas apa yang dilakukannya. Konkritnya, ada sepasang orangtua yang miskin tetapi bersih hatinya yang menutupi patung Jizou di pinggir jalan dengan caping. Pada akhir cerita, orang tua tersebut menerima buah dari kebaikannya dari jizou tersebut (Bellis, 2017).

Dongeng Jepang sering disebut dengan mukashi-banashi, diceritakan secara lisan dan turun temurun dari generasi ke generasi, sehingga terkadang sulit untuk mengetahui kapan anime dongeng tersebut pertama kali ditulis oleh pengarangnya. Mukashi artinya lampau, sedangkan hanashi artinya cerita. Selain itu karakteristik lain mukashi-banashi adalah tidak ditemukannya nama pengarangnya (anonim).

Dalam hal isi cerita, mukashibanashi biasanya berisi cerita pendek dan sederhana mengenai kepahlawanan, keteladanan, dan atau pesan moral lainnya. Dari sifat mukashi-banashi yang merupakan cerita yang lahir dan menyebar di kalangan rakyat banyak, maka mukashibanashi dapat dimasukkan ke dalam jenis folklor. Hal ini sesuai dengan pendapat Soeryawan maupun Danandjaja mengenai karakteristik folklor (Oktavia, 2015, p. 3).

\section{METODE}

Metode yang dipakai dalam artikel ini adalah metode sosiologi sastra, yaitu dengan mengungkap salah satu unsur struktur karya sastra dan kemudian mengaitkannya dengan konsep Mura menurut Inagaki. Unsur struktur yang diteliti latar,karena unsur ini adalah yang berkaitan langsung dengan "mura sebagai sebuah nama teritori di Jepang.

Latar merupakan salah satu unsur yang terdapat dalam suatu karya sastra. Sebuah karya sastra tentu terdapat latar sebagai unsur pembangun disamping tema, tokoh, alur, serta unsur intrinsik yang lainnya. Cerita hidup seorang tokoh dalam suatu karya sastra membutuhkan tempat, waktu, serta ruang lingkup yang harus dijelaskan sehingga lebih memudahkan pembaca untuk memahami situasi yang 
terjadi di dalam kehidupan. Latar dalam struktur karya sastra dapat dibedakan menjadi tiga, yaitu latar tempat, latar waktu dan latar sosial (Nurgiyantoro, 2012: 227).

Sedangkan konsep mura adalah salah satu dari tiga konsep sistem tradisional Jepang menurut Inagaki, yaitu mura, ie, dan kuni (Inagaki, 2018, p. 47). Berikut pemaparan secara singkat ketiga konsep tersebut.

\section{1). Mura}

Kata "mura" memiliki arti desa. Mura dalam konsep ini tidak boleh dipahami sebagai unit administrasi desa seperti "desa" pada pengertian masyarakat Indonesia pada umumnya, tetapi sebagai unit organisasi lokal untuk tujuan produksi dan sebagai komunitas yang terbentuk secara alami untuk dewa pemuja yang melindungi daerah, yaitu ubusunagami, ujigami atau shugoshin (dewa pelindung).

2). Ie

Kata Jepang yaitu mengacu pada rumah di mana orang tinggal, rumah, keluarga, tetapi selain makna yang lebih umum ini ada makna lain yang sulit diungkapkan dalam bahasa non-Jepang: ie juga merujuk pada "garis keturunan langsung dengan kesinambungan yang tak terputus dari masa lalu, memiliki konsep semacam identitas yang mencakup setiap generasi. Ie misalnya bertanggung jawab untuk melakukan ritual untuk mati dalam kategori waktu berikut: (1) dari konfirmasi kematian untuk penguburan, (2) dari pemakaman berakhirnya berkabung pada hari ke-49, (3 ) dari berakhirnya masa berkabung hingga tahun ke-33 (atau ke-50) yang menandai berhentinya massa peringatan bagi orang mati.

3). Kuni

Pandangan Jepang tentang leluhur dapat dikemukakan dalam tiga klasifikasi utama: 1) pandangan langsung, pengalaman nyata dari leluhur, 2) pandangan yang secara tidak langsung, pengalaman ideal tentang leluhur yang berkaitan dengan generasi keempat dan seterusnya, 3) pandangan buatan, ideologis, atau pandangan abstrak leluhur. Bentuk terakhir atau pandangan ideologis inilah yang kemudian dieksploitasi oleh pandangan bangsa Jepang modern tentang negara. Contoh dari eksploitasi tersebut termasuk "pengajaran nenek moyang" yang pada Era Meiji menguraikan moralitas kesetiaan kepada tuan dan orang tua; arti sebenarnya dari struktur nasional (1937) yang pada Zaman Showa mengajarkan penghormatan terhadap keluarga dan kerabat kaisar dan yang menguraikan pandangan negara sebagai satu keluarga besar.

\section{HASIL DAN PEMBAHASAN}

\section{Sinopsis Anime dongeng Kasajizou}

Pada zaman dahulu, di negara yang bersalju lebat, hidup sepasang orangtua yang miskin. Akhir tahun adalah saatnya untuk menyambut Tahun Baru. Tetapi untuk menyambut Tahun Baru, kue beras pun tidak mampu mereka beli. Oleh karena itu, obaasan meminta Kakek untuk menjualkan pakaian bekas mereka ke kota. Ojiisan pun memutuskan untuk pergi.

Di tengah perjalanan di pinggir desa, ojiisan mendapati ada tujuh buah patung "Jizou" yang menjaga desa. Patung tersebut terselimuti salju di kepala mereka. Merasa kasihan, ojiisan hanya bisa membersihkan salju yang menutupi kepala ketujuh patung Jizou tersebut. Karena tidak memiliki sesuatu barang yang bisa untuk menutupi patung tersebut dari salju, ojiisan kemudian melanjutkan perjalanan setelah meminta maaf terlebih dahulu kepada ketujuh patung Jizou tersebut.

Ojiisan akhirnya tiba di kota dan mulai menawarkan pakaian bekasnya kepada orang yang melintas. Akan tetapi, di tengah kesibukan orang mempersiapkan Oomisoka, tidak ada satupun orang yang menoleh dan melihat barang yang ditawarkan ojiisan. Akhirnya, sampai 
Kiryoku, Volume 3 No 22019

e-ISSN: 2581-0960 p-ISSN: 2599-0497

Tersedia online di http://ejournal.undip.ac.id/index.php/kiryoku

matahari tenggelam tidak ada satupun pakaian yang terjual.

Pada saat itu, ada penjual caping yang menyapa ojiisan dan memohon agar mau menukarkan pakaian dagangan ojiisan dengan sisa caping dagangannya yang berjumlah enam. Meskipun ojiisan tidak memerlukan caping-caping tersebut, akhirnya ojiisan setuju karena merasa iba melihat wajah penjual caping yang memelas.

Ojiisan kemudian pulang dengan membawa caping-caping tersebut. Ketika melintas di tempat patung jizou lagi, ojiisan sekali lagi melihat bagian kepala dari patung-patung jizou tersebut terselimuti dengan salju.

Ojiisan kemudian membersihkan kepala patung jizou dari salju dan mulai mengenakan caping yang dibawanya satu per satu. Karena capingnya hanya enam, ada satu patung jizou yang belum mendapat caping. Ojiisan dengan ikhlas melepas capingnya dan mengenakannya ke kepala patung jizou tersebut.

Sesampainya di rumah, obaasan merasa khawatir karena mendapati ojiisan tidak mengenakan caping. Ojiisan pun kemudian menceritakan kejadian tersebut. Mendengar penjelasan ojiisan, obaasan tidak merasa marah walaupun ojiisan tidak berhasil memperoleh uang untuk membeli keperluan oomisoka. Obaasan justru memuji ojiisan yang memberikan capingnya kepada para ojizousama yang terkena salju.

Ketika ojiisan dan obaasan tidur, mereka tiba-tiba dikejutkan dengan suara langkah kaki yang berat dan suara yang memanggil-manggil ojiisan. "Ojiisan no ie wa doko?" Kemudian mereka terkaget mendengar suara dentuman keras di depan rumah mereka. Ketika suara langkahlangkah kaki mulai menghilang, mereka memberanikan diri untuk melihat keluar. Ternyata di depan rumah mereka telah menumpuk bahan-bahan makanan yang diperlukan mereka untuk menyambut tahun baru. Dan dari kejauhan masih tampak para ojizousama yang berjalan menjauh menuju ke tempat mereka.

Akhirnya ojiisan dan obaasan dapat melewati tahun baru dengan kegembiraan.

\section{Pengertian dan Sejarah Mura}

Mura adalah kosakata bahasa Jepang yang artinya adalah village atau desa. (https://jisho.org/search/ 村 ). Sedangkan Berdasarkan wikipedia (Michey, 2003), pengertian mura dan sedikit mengenai sejarahnya adalah sebagai berikut.

村（むら、そん）とは、日本における普通地 方公共団体の一つ。近代化以前の「村」は自 然村（しぜんそん）ともいわれ、生活の場と なる共同体の単位だった。江戸時代には百姓 身分の自治結集の単位であり、中世の惣村を 継承していた。江戸時代にはこのような自然 村が、約 6 万以上存在した。明治時代に入ると、 中央集権化のため、自然村の合併が推進され た。こうして、かつての村がいくつか集まっ て新たな「村」ができたが、これを「自然村」 と対比して行政村（ぎょうせいそん）ともい う。

Dari kutipan diatas diketahui, bahwa mura atau desa adalah salah satu organisasi publik lokal biasa di Jepang. Sebelum modernisasi, mura" juga disebut desa alami (自 然 村, baca: shizenson), dan merupakan unit komunitas yang menjadi tempat hidup.

Pada zaman Edo, mura adalah unit pengorganisasian diri orangorang dengan status keluarga tertentu, dan mewarisi desa abad pertengahan souson (惣村). Ada lebih dari 60.000 desa alami seperti itu pada periode Edo. Di era Meiji, penggabungan desa-desa alami dipromosikan untuk sentralisasi. Dengan cara ini, beberapa bekas desa disatukan dan desa baru dibuat, tetapi ini kontras dengan "desa alami". Desa semacam ini disebut desa administratif (行政村, baca: gyouseison).

\section{Latar dalam Anime Kasajizou}

Berdasarkan latar tempatnya, diketahui 
bahwa latar tempat anime dongeng Kasajizou adalah desa dan kota yang berada di daerah yang memiliki curah hujan salju yang cukup tinggi. Seperti yang tergambar dalam gambar 1 , desa tempat ojiisan dan obaasan tinggal adalah desa yang sedang berada dalam timbunan salju yang cukup tebal.

Dilihat dari penggambaran desa yang tertutup tebal dan dialek bahasa yang dipakai dalam anime dongeng tersebut, kemungkinan adalah daerah yang berasal dari utara Jepang yang disebut sebagai yukiguni. Akan tetapi, dongeng Kasajizou adalah cerita yang didistribusikan secara luas di berbagai bagian Jepang selain wilayah Okinawa di mana tidak ada kepercayaan Jizou (Bellis, 2017). Oleh karena itu, masih terbuka kemungkinan asal dongeng Jepang ini berasal dari daerah lain di Jepang, kecuali wilayah Okinawa.

Berdasarkan latar waktunya, dapat diketahui bahwa latar waktu pada anime dongeng tersebut adalah pada saat oomisoka. Menurut wikipedia, oomisoka (大晦日) adalah hari terakhir dalam setahun di Jepang, menjelang tahun baru (Midori, n.d.). Masih dari wikipedia, ucapan perpisahan menjelang tahun baru adalah "Yoi otoshi o" ( 良いお年を， artinya semoga menjadi tahun yang baik untuk Anda). Ucapan "yoi otoshio" juga diucapkan oleh ojiisan untuk pedagang caping ketika mereka akan berpisah (gambar 2).

Meskipun diketahui bahwa salah satu latar waktunya adalah saat oomisoka, tetapi di dalam anime dongeng tersebut tidak diketahui secara pasti penggambaran zamannya. Hanya saja, dilihat dari penggunaan caping dan bentuk rumahrumah yang tergambar dalam anime tersebut, anime dongeng tersebut menggambarkan Jepang pada masa lampau.

Berdasarkan latar sosialnya, dapat diketahui bahwa ojiisan dan obaasan dalam anime dongeng tersebut adalah keluarga yang miskin. Selain itu, keluarga ojiisan dan obaasan tersebut adalah keluarga yang percaya bahwa desanya dijaga oleh dewa yang bersemayam dalam patung jizou. Selain itu, masyarakat yang tergambar dalam anime dongeng tersebut adalah masyarakat yang masih menjalankan tradisi Jepang. Salah satunya adalah tradisi oomisoka yang merupakan tradisi khas masyarakat Jepang.

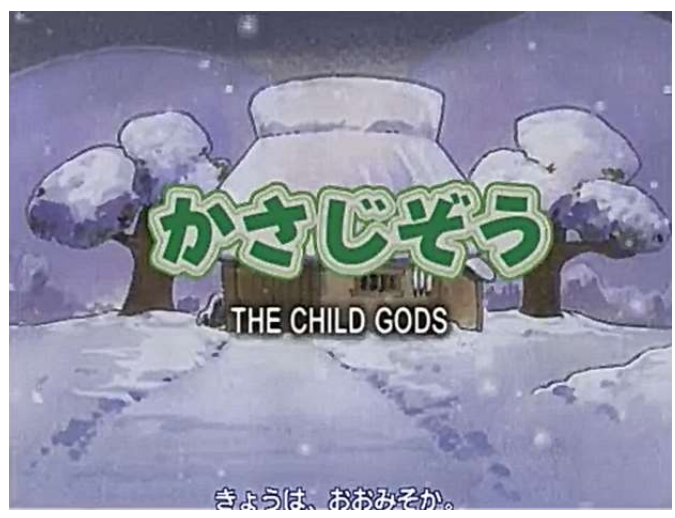

Gambar 1

(Sumber: https://www.youtube.com)

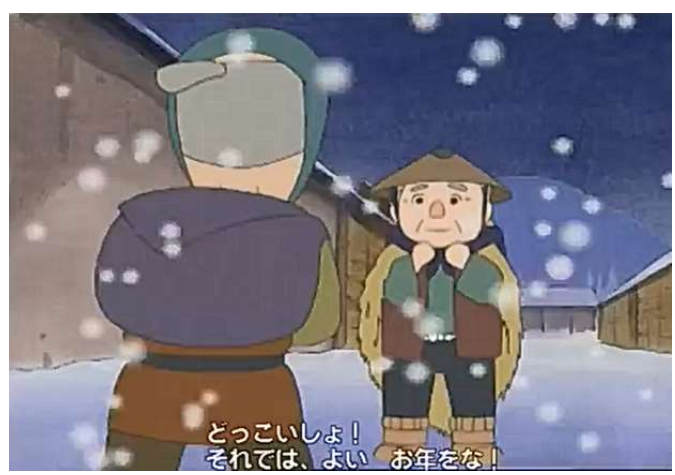

Gambar 2

(Sumber: https://www.youtube.com)

\section{Penggambaran Mura dalam Anime Dongeng Kasajizou}

Seperti yang terdapat pada gambar 3, penggambaran konsep "mura" dalam anime dongeng Kasajizou terlihat ketika ojiisan menjumpai tujuh patung "jizou" yang dianggap sebagai penjaga desa tersebut. Pada scene tersebut, narator mengucapkan kalimat berikut. 
Kiryoku, Volume 3 No 22019

e-ISSN: 2581-0960 p-ISSN: 2599-0497

Tersedia online di http://ejournal.undip.ac.id/index.php/kiryoku

むらはずれまで、たどりついた おじいさ ん。。そそこにさの村を見守っている 七人の おじぞうさまが いました。

Melihat ketujuh patung "jizou” yang tertutup salju pada kepalanya, ojiisan menyatakan rasa kasihannya kepada para patung "jizou" seperti yang terlihat pada perkataan ojiisan berikut.

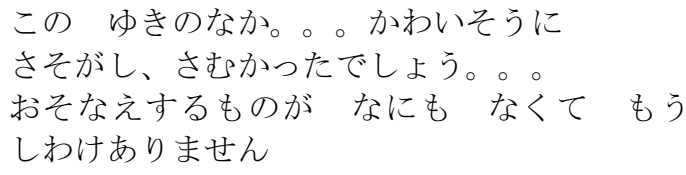

Pada kutipan di atas, ojiisan menyampaikan permintaan maaf kepada jizousama karena tidak membawa sesuatu yang dapat melindungi kepala jizousama. Dari hal tersebut dapat diketahui bahwa jizousama sangat dihormati oleh ojiisan karena alasan-alasan tertentu, salah satunya adalah karena dipercaya sebagai pelindung desa dari marabahaya.

Hal tersebut di atas sesuai dengan konsep mura seperti paparan Inagaki, yaitu terbentuknya mura adalah karena persamaan yang dimiliki sekelompok orang dalam menghormati dewa pelindung daerah tersebut yang mungkin bisa berbeda antara daerah yang satu dengan daerah yang lain. Hal itu diperkuat oleh paparan dalam wikipedia berikut.

地蔵に出会ったのは村と町の間、つまり境で あり、この境の神としての性質を持つ笠地蔵 の六地蔵は仏教の地蔵信仰ではなく\{\{疑問 点\}\}、年取りの日の出来事から見るに正月神 （歳徳神）の要素を持っており、秋田県のな まはげ、鹿児島県のトシドンのごとく家々を 訪れて幸をもたらすマレビトと根底は同じで あろう。地蔵の数も $1 、 3 、 6 、 7 、 12$ と土地に よって数に違いはあれども（こちらは本来の 地蔵信仰で六道の衆生を救済するという考え から）6体が一番多い。

Jizou ditemui antara desa dan kota, yaitu, di perbatasan, dan enam jizou yang memiliki sifat sebagai dewa perbatasan tersebut bukanlah Jizou seperti dalam agama Buddha. Ini memiliki unsur-unsur seperti Dewa Tahun Baru dan seperti Marebito, yang membawa keberuntungan, yang mengunjungi rumah-rumah di Prefektur Akita dan di Prefektur Kagoshima.jumlah Jizou berbeda antar daerah: 1, 3, 6, 7, 12 (ini dari ide menyelamatkan makhluk hidup dari enam cara dengan keyakinan Jizou yang asli); tetapi pada kepercayaan aslinya, paling banyak adalah enam buah.

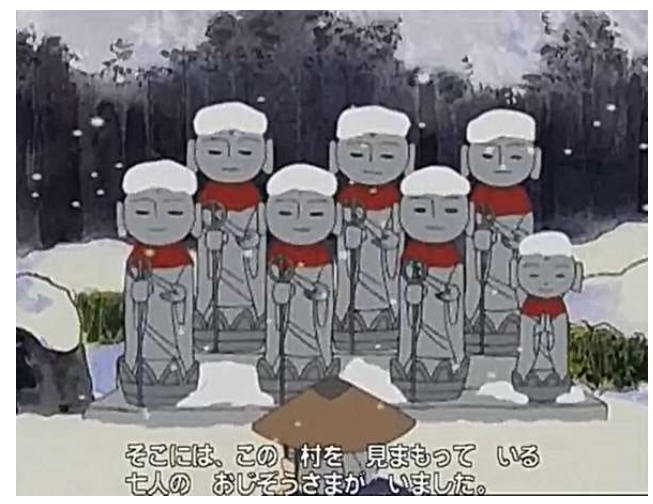

Gambar 3

(Sumber: https://www.youtube.com)

Seperti yang terlihat pada gambar 4, penghormatan ojiisan dan obaasan juga terlihat ketika mereka menyampaikan terima kasih atas pemberian ojizousama berupa bahan-bahan makan untuk keperluan oshougatsu (tahun baru). Ojizousama pada anime tersebut berjumlah tujuh.

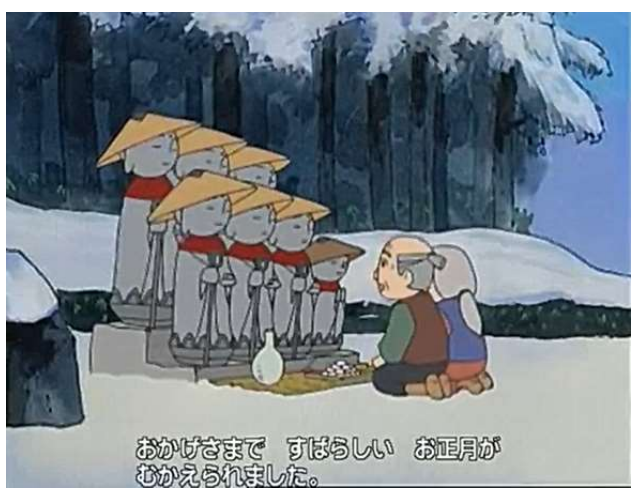

Gambar 4

(Sumber: https://www.youtube.com)

\section{SIMPULAN}

Anime Kasajizou diadaptasi dari salah 
Kiryoku, Volume 3 No 22019

e-ISSN: 2581-0960 p-ISSN: 2599-0497

Tersedia online di http://ejournal.undip.ac.id/index.php/kiryoku

satu versi dongeng Kasajizou yang berkembang di hampir seluruh masyarakat Jepang, kecuali di Okinawa. Latar tempat dalam anime tersebut menunjukkan pemandangan mura atau desa yang tertutup salju tebal. Selain itu pemakaian dialek bahasanya menunjukkan logat daerah utara Jepang yang disebut yukiguni. Mura dalam anime Kasajizou mirip dengan konsep "desa alami" atau mura yang dipaparkan Inagaki, yaitu mura yang terbentuk secara alami yang memiliki dewa pelindung desa yaitu para ojizousama.

Dari anime tersebut kita dapat memahami bahwa konsep mura atau desa dalam budaya Jepang, khususnya zaman dahulu, tidak sama dengan desa zaman kini yang lebih sering diasosiasikan dengan sebuah teritori atau wilayah administratif dalam suatu negara.

\section{DAFTAR PUSTAKA}

Bellis. (2017). 笠地蔵. Retrieved June 1, 2019, from https://ja.wikipedia.org/wiki/笠地蔵

Inagaki, H. (2018). A Philosophical Analysis Of Traditional Japanese Culture. Philosophia Reformata, 57(1), 39-56. Retrieved from https://www.jstor.org/stable/2470895 8

Kasajizou. (n.d.). Jepang: Es Entertainment Co, Ltd. Retrieved from https://www.youtube.com/watch?v=3 kzcFgS9BFU

Michey, M. (2003). 村. Retrieved June 1, 2019, from https://ja.wikipedia.org/wiki/村

Midori. (n.d.). Ōmisoka. Retrieved June 1, 2019, from https://id.wikipedia.org/wiki/Ōmisoka

Oktavia, L. W. (2015). Analisis Bandingan Unsur Intrinsik Legenda "Asal-Usul Danau Toba" Dan Mukashi Banashi "Tsuru No Hanashi." Japanese
Literature, 1(4), 1-25. Retrieved from https://ejournal3.undip.ac.id/index.ph $\mathrm{p} /$ japliterature/article/view/10950/106 20

Ryoko, K. (2019). National Character Studies Of Japanese. Social Thought and Research, 13(1), 69-78. Retrieved from https://www.jstor.org/stable/2325277 9

Suherman, E. (2004). Dinamika Masyarakat Jepang Dari Masa Edo Hingga Pasca Perang Dunia II. Humaniora, 16(2), 201-210.

(https://jisho.org/search/村). Diakses pada 1 Juni 2019. 